\title{
LEGAL PERSPECTIVE OF CHILD ADOPTION UNDER THE NIGERIAN LAW
}

\section{OLUWATOSIN O. OGWEZZY}

\section{Oluwatosin Omobolanle OGWEZZY}

Faculty of Law

Adekunleb Ajasin University, Akungba-Akoko, Nigeria

LL.B (Olabisi Onabanjo University, Nigeria), LL.M (Lagos, Nigeria),

B.L (Enugu, Nigeria)

Email: ogwezzytosin@gmail.com

\section{ABSTRACT}

Adoption is the process which creates a parent-child relationship between the adopted child and the adoptive parents with all the rights, privileges and responsibilities that attach to that relationship. Adoption severs a relationship between the child and the natural parents or guardians.The institution of adoption is important in society because it touches on status and therefore affects the rights and obligations of an adopted person. Adoption is recognized as one of the forms of alternative care for children who have been temporarily or permanently deprived of their family environment and also for children who are unable to remain in their family environment. This paper seeks to examine the adoption of a child under the Nigerian lawie. The statutory law, the customary Law ,procedure for adoption under Nigerian Lawand the legal effect of adoption of a child under the Nigerian Law.

KEYWORDS: adoption, child,juvenile,court,adopter,adopt

\section{INTRODUCTION}

Adoption means the taking of a child or young person into the family of a spouse whereby there is transferred to the spouse all the rights duties, obligations and liabilities of the natural parents in relation to the child or young person,as a result of which transfer the spouse stands to the child or young person in the position of his lawful parents. ${ }^{1}$ Thus by means of adoption, a family is continued through the artificial relationship for example, between a man and his wife on one hand, and a child on the other hand. Therefore the mere fact that a couple brings up an orphan does not automatically mean that they have adopted the child since the child may still be taken away from such a couple. Rather anyone or (any couple) wishing to bring up somebody else's child as his or (their) own has to apply for an adoption order from a court of competent Jurisdiction.

\section{MEANING OF ADOPTION}

The word "adoption" is the noun form of the verb "adopt". The word adopt has different connotations in different contexts.in the context of adoption as it relates to adoption of children, to adopt means "To take a child of other parents into one's own family becoming its legal parents ${ }^{2}$.In the words of DavidWatson, adoption is a legal procedure that permits a

\footnotetext{
${ }^{1}$ Section 2, Cap4,Laws of Edo State of Nigeria 2008

${ }^{2}$ Mairi Robinson and George Davidson (Editors)Chambers $21^{\text {st }}$ Century Dictionary,RevisedEdition,NewDelhi,allied Chambers(India )Limited,P.17
} 
child born to a person,or people to become in legal terms the son or daughter of another,or others, 'the adopter'.

\section{HISTORYOF CHILD ADOPTION UNDER THE NIGERIAN LAW}

Prior to 1965 ,there was no statutory regulation in any part of Nigeria for adoption. ${ }^{3}$ But in spite of such absence of legislation, there were instances of people adopting children as a result of agreement with parents of the children and of institutions taking care of orphans and destitute children. ${ }^{4}$ These arrangements could not be regarded as legal adoption .At best they were mere instances of foster parenthood or guardianship. ${ }^{5}$ The unfortunate result was that the child's natural parents or guardian might at any time assert their parental rights by demanding the return of the child . there was therefore perpetual fear that the couple might lose the child to its natural parents in spite of close relationships which may have developed between them ${ }^{6}$.The first attempt at providing statute on adoption was a private member bill presented to the then eastern House of Assembly. ${ }^{7}$ It was followed by the adoption Laws of Lagos State $1968 .{ }^{8}$ Other States subsequently legislated for adoption. These were Bendel State $(1979)^{9}$ now Edo state ${ }^{10}$,Ogun State $(1983)^{11}$ and Oyo State $(1984)^{12}$.These Laws have substantial similarities though some differences exist. ${ }^{13}$ However, with the promulgation of the Child's Right Act of 2003(CRA) the previous enactments made on adoption have beenovertaken by its provisions .Hitherto, where inconsistency exits between the (CRA) and these earlier provisions, the latter would give way. ${ }^{14}$ States are however expected to adopt the CRA. For those states that have adopted it, it becomes law for them. For those who have not adopted it, their old law remains, unless they have adopted the amended part of the CRA. ${ }^{15}$

\section{TYPES OF ADOPTION UNDER THE NIGERIAN LAW.}

There are two basic forms of adoption in Nigeria.These are Customary and Statutory Adoption.

\subsection{Customary adoption}

Customary adoption may be formal or informal. ${ }^{16}$ The process of formal customary adoption starts by a meeting of the families of the child to be adopted and that of the person seeking to adopt the child. The purpose of this meeting is to formally transfer the parents' rightsand duties of the child to the person seeking to adopt the child, which is a crucial aspect of the adoption. Upon such transfer,the adopter then publicly declares his intention to regard the child in question as his own. This ceremony is sealed up with the sharing of a prepared meal together among the families. ${ }^{17}$ Customary law of adoption is practiced in some parts of

\footnotetext{
${ }^{3}$ Enemo I.P, Basic Principles of Family Law in Nigeria, Ibadan: Spectrum Books Limited, 2008, p 314

${ }^{4}$ For example missionary societies

${ }^{5}$ NwoguguE.I,Family Law in Nigeria,Ibadan:HEBN publishers plc,Revised Edition 1990,p.312.

${ }^{6}$ Ibid

${ }^{7}$ Ibid.

${ }^{8}$ No.5 of 1979. SeeEnemoI.P,op.cit p.315

${ }^{9}$ No .7 of 1981.See EnemoI.P,op.cit

${ }^{10}$ Cap4,Laws of Edo State of Nigeria 2008

${ }^{11}$ No.3 of 1983.See Enemo I.P,op.cit,p.315

${ }^{12}$ No.4 of 1984.See Enemo I.P,op.cit,p315

${ }^{13}$ Enemo I.P,op.cit,p315

${ }^{14}$ Section 12 of the Child's Right Act,SeeEnemoI.P,op.cit p.315

${ }^{15}$ Enemo I.P,op.cit.p. 315

${ }^{16}$ Osondu A.C ,Modern Nigerian Family Law \&Practice.Lagos,Printable Publishing Company,2012,p.257

${ }^{17}$ Ibid.
} 
Iboland,Yako tribe of plateau State,Okrika of Rivers State,Ishan of Edo State,Egbas of Yorubaland amongst others.For example under the Yoruba land in Akinwandev.Dogbo ${ }^{18} \mathrm{X}$ took the child of his deceased sister into his household and the child lived there over a long period of time. During this time, $\mathrm{X}$ was responsible for the child's maintenance and upbringing.Thompson,j.held that the child was adopted by X's under customary law. This decision brings out the defects of customary law adoption.for instance $\mathrm{X}$ 's responsibility for the maintenance and upbringing of the child is capable of several interpretations including evidence of guardianship or adoption.On the other hand, an informal adoption is not characterized by any formalities. It occurs Upon the person seeking to adopt taking the child, usually the child of a relative, into his own family and treats the child as his own. ${ }^{19}$ This is a common feature of African societies due to the extended family system. ${ }^{20}$ Adoption under the English law permanently extinguishes all the rights, liabilities and duties of parents in relation to the child, the so called customary adoption does not permanently severe or annul the legal relationship between the child and its natural parents. ${ }^{21}$

\subsection{Statutory Adoption}

Statutory adoption is a formal and legal type of adoption governed by the provisions of statutory lawsi.e written law. The adoption laws of the various states where such laws exist govern statutory adoption in those states. Such laws usually provide for the qualifications of persons eligible to adopt and be adopted, conditions for adoption, consents required before adoption,procedures to be followed in adoption matters and the legal effects in adoption.one distinguishing feature of statutory adoption from customary adoption is the fact that while statutory adoption permanently extinguishes the rights and legal relationship between the child and his natural parents, this is not so under customary form of adoption where the rights and legal relationship between the child and the natural parents remains intact. ${ }^{22}$

\section{WHO MAY ADOPT}

In all existing adoption laws in Nigeria, any person may be authorized by the court to adopt a child.There are certain general rules however,which cut across all states. ${ }^{23}$ Except where joint application is made by husband and wife,only one person will be allowed to adopt a child. ${ }^{24}$ Thus an applicant for an adoption order may be sole male or female.where a sole applicant is a male he will not be allowed to adopt a female child unless there are exceptional circumstances in the opinion of the court, would justify the making of such order. ${ }^{25}$ The essence of this prohibition is to guard against the danger of sexual corruption of the female child.where a married person is the sole applicant for an adoption order, the court may require that the consent of the other spouse be obtained ${ }^{26}$. The Child's Right Act ${ }^{27}$ has specified in any

\footnotetext{
${ }^{18}$ Suit AB/26/68(unreported)High court ,Abeokuta.14 July 1969.See E.I Nwogugu,Family Law in Nigeria .Third Edition 2014,p.344

${ }^{19}$ Osondu A.C,p.257

${ }^{20}$ Ibid.p. 258

${ }^{21}$ Ibid.

${ }^{22}$ Ibid.

${ }^{23}$ ERLaw,Section 3(1); Lagos Section 2(1),Bendel Section 3;Cross River Section1(1),Ogun Section.5(1).See Enemo I.p.op.cit,p.317

${ }^{24}$ ERLaw,Section 3(2) and 3(3);Lagos Section2(3);Bendel,4(2);Cross river Section1(2);Ogun ,Section5(2).See Enemo I.P,p.317.

${ }^{25}$ ER Law,Section 4(2);Lagos,Section3(3);Bendel,Section 5(1)(2);Cross River,Section3(1);Ogun,Section7(1) .See Nwogugu E.I, Revised Edition,P.314.

${ }_{26}$ ER Law,Section 6(2);Lagos ,Section4(1);Bendel,Section6(1);Cross River, Section3(1)Ogun.Section 7(1).See NwoguguE.I,Revised Edition,P.314.
} 
way that an adoption order shall not be made unless the applicant is acitizen or,in the case of a joint application,both applicants are citizens of Nigeria. ${ }^{28}$ It seems that a child who is not a Nigerian Citizen but who resides within a state in Nigeria where the machinery for adoption exists, may be adopted,since all the laws are silent on the matter. ${ }^{29}$

\section{WHO MAY BE ADOPTED}

Under the relevant adoptions laws,the only person that can be adopted is a juvenile.A Juvenile is defined in some states ${ }^{30}$ as a person under seventeen years of age while some others apply a higher age limit of eighteen years. ${ }^{31}$ The Childs Rights Act of 2003 provides for a child to be a person under the age of 18 years. ${ }^{32}$ The Oyo State law uses the term 'child' instead of Juvenile and it means a person under the age of 18 years who has never been married.

In former Bendel ${ }^{33}$ and Lagos ${ }^{34}$ an adoption order may only be made in respect of a juvenile "who is abandoned, or whose parents and other relatives are unknown or cannot be traced after due inquiry certified by juvenile court ${ }^{\prime 35}$ The problem in these states is that once the parents of achild were known, he or she cannot be subject of an adoption order.

The former Ogun State Adoption $\mathrm{Law}^{36}$ is similar to that of Lagos and Bendel States in this respect, but also includes that "unwanted babies of unmarried mothers who are incapable of taking care of them and whose natural fathers are either unknown or cannot be traced,or where known do not want the babies of insane mothers who have no willing to take care of them could also be subjects of an adoption order." This provision is not all encompassing because achild should be capable of being a subject of an adoption order whether or not the parents cannot be traced,provided that in making the order, the best interest of the child is of paramount consideration. Section (1) of the Childs Rights Act even provides that in every action concerning a child the best interest of the child shall be the primary consideration. In Former Anambra,Imo,Rivers and Cross River states adoption orders may be made in respect of any child within the prescribed age whether or not the parents and the relatives are known. ${ }^{37}$ In former Oyo State, the child to be adopted must in addition to the age limit be a person who has never been married. ${ }^{38}$ However the Childs Rights Act has put the marriageable age at 18years, which means that such children that may be adopted would not be married during the adoptable years. Under section128 of the Childs Rights Act, a child who is abandoned, neglected or persistently abused or ill-treated, may be adopted, and also a child whose parents are known may also be adopted and also a child whose parents are known may also be adopted provided they give their consent. Therefore whether child is abandoned

\footnotetext{
${ }^{27}$ CAP C50Laws of Federation(LFN)2004.

${ }^{28}$ Section 131(d) of the Child's Right Act.

${ }^{29}$ Enemo I.P op,cit,o.320.

30 Former Anambra,Imo,Rivers States (E.R.Law,Section 2).Lagos Section .1), and Ogun (Section 2)States.SeeEnemo I.p,op.cit,p.316.

${ }^{31}$ Former Bendel(Section 2),Cross River(Section 20) and Oyo(Section 2)States.

${ }^{32}$ Section 277

${ }^{33}$ Section 3(1).See Enemo ,I.P,Op.cit,p.316.

${ }^{34}$ Section 3.See Enemo, I.P op.cit,,p.316.

${ }^{35}$ Section 1(1)Lagos.SeeEnemo I.P,op.cit,p.316

${ }^{36}$ Section 3.See Enemo I.P,Op.cit,p.316.

${ }^{37}$ Enemo I.P.op.cit.p.317.

${ }^{38}$ Section 3,Oyo State Law. SeeEnemo I.P,op.cit,p.317.
} 
or not, legitimate or illegitimate, such a child can be adopted as long as the necessary consents are obtained.

\section{CONSENTS REQUIRED BEFORE ADOPTION}

Where a married man or woman is the sole applicant for the adoption of a juvenile, the consent of the other party to the marriage shall be obtained before an adoption order is made. Similarly, where a person other than the father or mother or relative of a juvenile has any rights or obligations in respect of the juvenile under any order of a court or any agreement or under customary law, the court may refuse to make an order until the consent of that person is first obtained. ${ }^{39}$ Such consent may be given conditionally or unconditionally ${ }^{40}$.In the case of an illegitimate child,the consent of the mother shall be required before an adoption order is madein respect of the child. ${ }^{41}$

\section{PROCEDURE FOR ADOPTION UNDER THE NIGERIAN LAW}

The Child's Right Act, $2003^{42}$ provides for adoption of a child in Nigeria. An application for adoption is made to the High (Family) Court accompanied with the following documents;

(a) Where the applicant is a married couple, their marriage certificate or a sworn declaration of marriage; ${ }^{43}$

(b) The birth certificate or sworn declaration of age of each applicant; ${ }^{44}$

(c) 2 passport photographs of each applicant; ${ }^{45}$

(d) A medical certificate of the fitness of the applicant from a Government hospital; ${ }^{46}$ and

(e) Such other documents, requirements and information as the Court may require for the purposes of the adoption ${ }^{47}$.

In practice, the Court prefers that an applicant must have fulfilled the condition precedent at the Child Welfare Department and obtain a report stating that the applicant is a proper person to adopt the child. The report would accompany the application for adoption.

Upon receipt of an application for adoption, the Court shall order an investigation to be conducted by child development officers or a supervision officer or such other persons as the Court may determine, to enable the Court to assess the suitability of the applicant as an adopter and of the child to be adopted ${ }^{48}$.

The Court shall, in reaching a decision relating to the adoption of a child, have regard to all the circumstances, first consideration being given to the need to safeguard and promote the welfare and the best interest of the child throughout the childhood of that child and ascertaining, as far as practicable, the wishes and feelings of the child regarding the decision

\footnotetext{
${ }^{39}$ OsonduA.C,op.cit ,p. 266

${ }^{40}$ Section 4(1) of the Adoption Law of Lagos State.SeeOsondu A.C ,op.cit.

${ }^{41}$ Osondu,A.C,op.cit,p. 267

${ }^{42}$ Section 126(1)CAP C50LFN 2004.

${ }^{43}$ Section 126(a)CAPC50LFN2004.

${ }^{44}$ Section 126(b)CAPC50LFN2004.

${ }^{45}$ Section 126(c)CAPC50LFN2004.

${ }^{46}$ Section126(d)CAPC50LFN2004.

${ }^{47}$ Section126(e)CAPC50LFN2004.

${ }^{48}$ Section 126(2)CAPC50LFN,2004.
} 
and giving due consideration to those wishes and feelings, having regard to the age and understanding of the child ${ }^{49}$.

\section{LEGALEFFECTS OF ADOPTION UNDER THE NIGERIAN LAW}

The legal effects of adoption of an adoption order are primarily two-fold. First it severs all parental rights and obligations between the juvenile and his natural parents. Second and of immense importance, it establishes the legal relationship of parent and legitimate child between adopter and the adopted juvenile. In respect of custody, maintenance and education, the juvenile shall stand to the adopter and the as if he was born in lawful wedlock. ${ }^{50}$ Where the juvenile is jointly adopted by husband and wife, then in respect of the custody, maintenance and education of the juvenile, they will occupy the position of natural parents. ${ }^{51}$

\subsection{Intestacy}

If after an adoption order has been made an adopter dies intestate, his estate shall devolve as if the adopted person were his lawful child. ${ }^{52}$ But an adopted person has no right to succeed to property if his natural parents die intestate since all legal connections with them have been severed by adoption order. ${ }^{53}$

\subsection{Construction of Settlement and Will}

In any property disposition of property made by instrument inter vivos or by will after the date of adoption order, any reference to the 'child', or children of the adopter, includes the adopted person. ${ }^{54}$ It is necessary to note that disposition by will or codicil takes effect from the date of the testator's death rather than on the day it was made. Consequently, it may transpire for example, that X made a will in May 1964.In July 1967, he adopted y.He died in December 1968.Y will be entitled to share in any gift or disposition made generally to the 'children' of X.As a corollary, the adopted person ceases on his adoption to be regarded as a child of his natural parents in respect of testate and intestate succession. A person adopted jointly by two spouses will be regarded as a brother or sister to the natural or adopted children of the adopters for the purposes of administration of estates. ${ }^{55}$ Moreover a person related to the adopted person in any degree shall unless a contrary intention appears, be regarded as if he would be related to himin that degree if he were of the adopter. ${ }^{56}$

\subsection{Effect of Adoption on Maintenance Order}

Where at the time when and adoption order is made in respect of a juvenile an order requiring any person to contribute towards the juvenile's maintenance under the children and young person's Act is in force,the latter shall cease to have effect at that time. ${ }^{57}$

\section{PROHIBITED ACTS IN RESPECT OF ADOPTION ORDERS}

A number of acts are made punishable if committed against the prohibition of law made in respect of adoption orders.

\footnotetext{
${ }^{49}$ Section126(3)CAPC50LFN,2004.

${ }^{50}$ ER Law section 13(2);CrossRiver, section 10(2).

${ }^{51}$ ER Law section 13(2);Lagos section12(3);Bendel section 14(2);Cross river,section10(3).

${ }^{52}$ ER Law section 14(1);Lagos section 13;Bendel, section 15;Cross River, section 11;Ogun section 16

${ }^{53}$ ER Law section 14(1);Lagos section 13;Bendel, section 15;Cross River, section 11;Ogun section 16;Section141(3) of Childs Right Act CAP C50LFN2004.

${ }_{55}^{54}$ ER Law,section14(2);Lagos, section 4,Bendel section 16;Cross River, section 12; Ogun,section 17.

${ }^{55}$ ER Law, section 15(1)

56 ER Law, section 14(1)(c);Lagos, section 14(b);Bendel,section $16(\mathrm{~b})$; Cross River,section12(b);Ogun,section17(b).

${ }^{57}$ Lagos, section 15; Bendel,section 17, Cross River, section 13, Ogun ,section 18.
} 


\subsection{Prohibition Of Marriage BetweenAn Adopter And The Adopted Juvenile}

Marriage between an adopter or his natural child and a juvenile adopted by him is prohibited. The same is true in respect of any juvenile adopted under a separate adoption order.Consequently, an adopted son, forinstance, cannot marry the daughter of his adopter or a female adopted by the same person because the effect of the adoption orders is to create blood relationship between them. The violation of the prohibition is made punishable with five years of Imprisonment. ${ }^{58}$

\subsection{Prohibition of certain payments}

It is unlawful for an adopter or any other person to receive any payment or reward in consideration of the adoption of a juvenile or for the facilitation of the arrangement thereof unless with the leave of court.The punishment for the contravention of this rule is a fine or imprisonment or both. ${ }^{59}$

\subsection{Restriction on Sending Juvenile Away for Adoption}

All the adoption laws under consideration make it unlawful to permit the care and possession of a juvenile to be given to any person outside the stat for the purposes of the juvenile being adopted here.The sanction for the violation of this rule consists of a fine or imprisonment or both. ${ }^{60}$

\section{CONCLUSION}

This paper has examined meaning ,types of adoption available in Nigeria, who may adopt,who may be adopted ,consent before adoption,procedure for adoption and adoption maintenance order.The most significant aspect of adoption of child or juvenile under Nigerian law is the fact that it extinguishes the rights and obligations of the natural parents and transfer such rights and obligations to the adopter.Thus, adoption confers on the child all the rights vis-à-vis his adoptive parent(s) as if the child has been born to them in lawful wedlock as well as imposes on the adoptive parent(s) parental responsibility equivalent to that of the natural parents of the child.

\footnotetext{
${ }^{58}$ ER Law, section 13(4);Lagos, section 22;Bendel,section 24;Cross River, section 18;Ogun section 25.

${ }^{59}$ ER Law section 17,lagos,section 17;Bendel,section 19;Cross River section 15;Ogun,section 20;Oyo,section12.

${ }^{60}$ Lagos,section18,Bendel section 20,Cross River, section 16;Ogun,section 21,Oyo ,section 15.
} 